\title{
The Frequencies and Clinical Correlates of Neurological Symptoms in COVID-19
}

COVID-19’da Nörolojik Semptomların Sıklığı ve Klinik Korelasyonlarının Araştırılması

\author{
Abdulkadir Tunç, Murat Alemdar, Meral Seferoğlu, Yonca Ünlübaş, Mustafa Karabacak, \\ Sena Boncuk, Alper Eryılmaz, Tuna Eker
}

Sakarya University, Sakarya Training and Research Hospital, Sakarya, Turkey

Yazıฺ̧̧ Adresi / Correspondence:

Abdulkadir Tunç

Sakarya University, Sakarya Training and Research Hospital, Sakarya, Turkey .

T: +905545144524 E-mail : drkadirtunc@hotmail.com

Geliş Tarihi / Received : 18.01.2021 Kabul Tarihi / Accepte: 02.08.2021

Orcid :

Abdulkadir Tunç https://orcid.org/0000-0002-9747-5285

Murat Alemdar 0000-0001-7127-3119

Meral Seferoğlu https://orcid.org/0000-0003-3858-0306

Yonca ÜNLÜBAȘ https://orcid.org/0000-0002-2189-3480

Mustafa Karabacak https://orcid.org/0000-0002-0117-1763

Sena Boncuk 0000-0002-0076-9405

Alper Eryılmaz 0000-0002-4979-3684

Tuna Eker https://orcid.org/ 0000-0002-0622-0923

( Sakarya Tip Dergisi / Sakarya Med J 2021, 11(3):616-624) DOI: 10.31832/smj.863568

\footnotetext{
Öz

Objective Coronavirus disease 2019 (COVID-19) may cause neurological impairments in addition to disorders of respiratory and gastrointestinal systems. We aimed to investigate the frequencies and clinical correlates of neurological symptoms in COVID-19.

Materials This descriptive cross-sectional study was conducted with 117 consecutive patients diagnosed as having COVID-19 in two designated centers assigned by the government and Methods to follow up the COVID-19 patients in Turkey.

Results The mean age was $53.08 \pm 15.63$ years (range 18 to 89 years). Sixty-five (55.5\%) mildly (non-complicated), 32 (27.4\%) moderately (mild pneumonia), and 20 (17.1\%) severely ill (severe pneumonia) patients are included. Seventy nine patients (67.5\%) were detected to suffer from neurological complaints. The most common symptom was taste impairment seen in $36(30.7 \%)$ patients. Other common complaints were smell impairment (25.6\%), headache (24.7\%), and dizziness (16.2\%). Patients with neurological symptoms were younger, and more likely to have accompanying comorbidities. The patients with severe infection were also more likely to have coexisting comorbidities. Higher ferritin and LDH levels, and lower lymphocyte counts indicated the worse disease severity.

Conclusion Our results demonstrated that more than half of the non-critically ill COVID-19 patients experiences neurological complaints. Clinicians should be aware of the neuroinvasive spread of the coronaviruses, and neurological symptoms should be questioned in particular the young patients with accompanying comorbidities.

Keywords SARS-CoV; COVID-19; Pandemics; neurological symptoms
}

\section{Abstract}

Amac Koronavirüs hastalı̆̆ 2019 (COVID-19), solunum ve gastrointestinal sistem bozukluklarına ek olarak nörolojik bozukluklara da neden olabilir. Bu calısmada COVID-19 hastalarında nörolojik semptomların sıklı̆̆ ve klinik korelasyonlarının araştırılması amaçlandı.

Gereçve Bu kesitsel tanımlayıcı çalısma, Türkiyedde COVID-19 hastalarımı izlemek için Sağlı Bakanlığı tarafindan yetkilendirilen iki pandemi hastanesinde COVID-19 teșhisi konulan 117 ardısılk

Yöntemle hasta ile gerçekleștirildi.

Bulgular Hastaların ortalama yaşı $53.08 \pm 15.63$ yıldı (18-89 yaş aralı̆̆ı). Çalışmaya altmış beş (\%55,5) hafif (komplike olmayan), 32 (\%27,4) orta (hafif pnömoni) ve 20 (\%17,1) ağır (ağır pnömoni) hasta dahil edildi. Yetmis dokuz hastanın (\%67,5) nörolojik yakınmaları olduğu tespit edildi. En sik görülen semptom 36 (\%30.7) hastada görülen tat bozukluğuydu. Diğer yaygin sikayetler koku alma bozukluğu (\%25.6), bas ağrısı (\%24.7) ve bas dönmesiydi (\% 16.2). Nörolojik semptomları olan hastalar daha gençti ve eslik eden komorbiditelere sahip olma olasiliğı daho yüksekti. Şiddetli enfeksiyonu olan hastaların aynı zamanda eşlik eden komorbiditelere sahip olma olasıllğı da daha yüksekti. Daha yüksek ferritin ve LDH seviyeleri ve daha düşük lenfosit sayıları, daha kötü hastalık seyri ile korele bulundu. Buna karșıllk laboratuvar parametrelerinin sonuçları nörolojik semptomları olan ve olmayan hastalar arasında farklı değildi. Çalı̦ma grubumuzda komorbidite sayısı ve sigara içme durumu, hastalık șiddeti ve nörolojik semptomların varlı̆̆ i ile ilișkili değildi.

Sonuৎ̧ Sonuç olarak, bulgularımız kritik hastalı̆̆ olmayan COVID-19 olgularının yarısından fazlasının nörolojik sikayetler yasadı̆̆ını göstermistir. Klinisyenler, koronovirüslerin nöroinvazif yayılmasından haberdar olmalı ve bu hastalarda, özellikle eşlik eden komorbiditeleri olan gençlerde nörolojik bozuklukları sorgulamalıdır. Hastaların ilk veya erken șikayetleri olabileceğinden, COVID-19'un nörolojik semptomlarıı daha iyi tanımak, pandeminin kontrolü için özel bir öneme sahip olan erken tanı oranını artırmak için acil bir ihtiyaçtır.

Anahtar SARS-CoV; COVID-19; Pandemi; nörolojik semptomlar 


\section{INTRODUCTION}

The novel severe acute respiratory syndrome coronavirus 2 (SARS-CoV-2) causing coronavirus disease 2019 (COVID-19) was first detected in December 2019. ${ }^{1}$ Approximately 198.038 million cases have been reported up to date, including approximately 5.727 .045 confirmed cases in Turkey. ${ }^{2}$ SARS-CoV-2 shares fairly similar gene sequences with SARS-CoV according to genomic analysis, and it's characterized by clinical symptoms similar to those reported for SARS-CoV and MERS-CoV. ${ }^{3}$ The prominent symptoms of COVID-19 are fever, cough and fatigue, as well as shortness of breath. In severe cases, patients develop pneumonia, acute respiratory distress syndrome (ARDS), acute cardiac problems, and multiple organ failure. ${ }^{4,5}$ Accumulating evidences suggest that coronaviruses are not always limited to the respiratory tract, and could also have neuroinvasive abilities and might spread from the respiratory system to the central nervous system $(\mathrm{CNS}){ }^{6-8}$

Recent studies reported that patients with COVID-19 could have several neurological symptoms, such as headache, distortion of smell sensation hyposmia/anosmia, distortion of taste sensation (dysgeusia), dizziness, and impaired consciousness. ${ }^{6-10}$ The rate of neurological symptoms has been reported between $21 \%$ and $67 \%{ }^{6,11,12}$ Therefore, with the now ongoing pandemic, it is necessary to explore specific neurological features of the disease and make clinicians aware of the impact of the infection on the CNS. The objectives of our study are to research the frequencies of neurological symptoms in COVID-19 patients and their associations with the demographic features, severity of illness, other clinical symptoms, and laboratory parameters.

\section{MATERIALS and METHODS}

This descriptive cross-sectional study was performed in Xx Education and Research Hospital (Xx, Turkey) and Xxx Yüksek İhtisas Education and Research Hospital (Xxx, Turkey) which were designated centers assigned by the government to follow up the COVID-19 patients.
Consecutive hospitalized patients diagnosed as having COVID-19 according to WHO interim guidance 6 were enrolled between April 10 to May 1, 2020 (67 patients from the 1 st center, 50 patients from the 2 nd center). This study was approved by the ministry of health which is mandatory in our country during the pandemic. Than the ethical approval was obtained from the Ethics Committee of Xx University for NonInterventional Studies (Date: 20.05.2020 - No:71522473/7050.01.04/235).

The diagnosis of all patients were confirmed by the real-time reverse-transcription-polymerase-chain-reaction (RT-PCR) assay for the COVID-19 from the oropharyngeal and nasopharyngeal swabs. The RT-PCR samples were placed into a collection tube containing preservation solution for the virus. Detailed laboratory tests (a blood chemical analysis, assessment of liver and renal function testing, lactate dehydrogenase (LDH), complete blood cell count, C-reactive protein (CRP), ferritin, and D-Dimer) and chest computerized tomography (CT - if not pregnant) were performed at admission for each patient, routinely.

Age, gender, accompanying comorbidities (diabetes, hypertension, chronic respiratory disease, chronic hearth or kidney disease, etc.), pregnancy and smoking status, contact history with confirmed patients with COVID-19, typical symptoms from onset to hospital admission cough, fever, neurological symptoms, and results of the laboratory tests were recorded. The definition of positive neurological symptoms required that the patients have at least one of the following newly emerged symptoms: headache, dizziness, vertigo, ataxia, taste impairment, smell impairment, impaired consciousness, numbness and paresthesia, motor or sensory deficits, and seizure. Fatigue and myalgia were questioned separately from neurological complaints. To avoid the influence of other medical therapy and external factors, neurological symptoms were recorded on admission. Cranial CT and MRI were performed if necessary, in particular for the suspicion of acute stroke or encephalitis. COVID-19 patients were analyzed in 5 subgroups ac- 
cording to the degree of disease severity based on the new coronavirus pneumonia diagnosis and treatment program which was published by the National Science Commission of Turkey. ${ }^{13}$ An asymptomatic case was defined as a RT-PCR confirmed case with normal body temperature or minor discomfort. A mild (non-complicated) case was defined as a RT-PCR confirmed case with fever, muscle / joint pain, cough, sore throat and nasal congestion, and without respiratory distress, tachypnea, and radiographic evidence of pneumonia. (oxygen saturation $(\mathrm{SaO} 2) \geq 93 \%$, lymphocyte count $\geq 800 / \mu \mathrm{l}$ or CRP $\geq 40 \mathrm{mg} / \mathrm{l}$ or ferritin $<500 \mathrm{ng} / \mathrm{ml}$ or D-Dimer $\leq 1000 \mathrm{ng} / \mathrm{ml})$. Patients with mild pneumonia (moderate group) were defined as a RT-PCR confirmed case with fever, muscle / joint pain, cough, sore throat and nasal congestion, and radiographic evidence of mild pneumonia in chest computed tomography (CT). $(\mathrm{SaO} 2 \geq 90 \%$, respiratory rate $<30 / \mathrm{min})$. Patients with severe pneumonia (severe group) were defined as a RT-PCR confirmed case with fever, muscle / joint pain, cough, sore throat and nasal congestion, and radiographic evidence of bilateral wide pneumonia evidence in chest CT. $(\mathrm{SaO} 2>$ $90 \%$, respiratory rate $<30 / \mathrm{min}$ ). Critically ill patients were defined as a RT-PCR confirmed case with radiographic evidence of bilateral wide pneumonia evidence in chest CT. $(\mathrm{SaO} 2<90 \%$, respiratory rate $\geq 30 / \mathrm{min})$.

Critically ill patients were not included in our study because they were followed up in the intensive care units. All patients included in this study were in mild, moderate or severe illness group. There was also no asymptomatic patients.

\section{Statistical Analysis}

All data was analyzed by using the Sofastat programme (Paton-Simpson \& Associates Ltd, Auckland, New Zealand). After test for normality, the statistical significance was researched by using an independent sample t-test or ANOVA for normally distributed data, and using MannWhitney U' test or Kruskal Wallis-H test for non-normally distributed data. Chi-Square test was used to analyze the association between categorized variables. Fisher Exact Probability Test was used for tables larger than $2 \times 2$ when needed. A p value $<0.05$ was considered as statistically significant.

\section{RESULTS}

A total of 117 hospitalized patients with confirmed SARS$\mathrm{CoV}-2$ infection were enrolled in the study. The mean age was $53.08 \pm 15.63$ years (range 18 to 89 years), and 60 were men $(51.2 \%)$. There was a history of contact with cases of confirmed COVID-19 in 55 (47\%) patients. Among them, $42(35.8 \%)$ had contact with infected family members, and 13 (11.1\%) with others (co-worker, neighbor, friend). Considering the classical COVID-19 symptoms, there were cough in 81 (69.2\%), fever in 43 (35.8\%), and fatigue in $44(37.6 \%)$ patients. The most prevalent comorbidities were hypertension (33.3\%), diabetes (19.6\%), chronic respiratory diseases $(11.9 \%)$, cardiac disease $(8.5 \%)$, and chronic renal disease (7.6\%). Sixty-eight (58.1\%) patients had at least 1 comorbidity.

Seventy nine patients $(67.5 \%)$ were detected to suffer from neurological complaints. The most common symptom was dysgeusia seen in 36 (30.7\%) cases. Other complaints were hyposmia/anosmia $(\mathrm{n}=30(25.6 \%))$, headache $(\mathrm{n}=29$ $(24.7 \%))$, and dizziness $(\mathrm{n}=19(16.2 \%))$. Additionally, 4 patients had numbness or paresthesia, 6 patients had impaired consciousness, 1 patient had cerebellar ataxia, and 1 patient was diagnosed with acute cerebral stroke (middle cerebral artery occlusion). The mean time from illness onset to neurological complaint onset was $2.57 \pm 2.98$ days. There was no significant correlations between the time of the onset of neurological symptoms and gender, presence and number of comorbidities, and disease severity ( $\mathrm{p}>$ 0.05). The mean age, number of comorbidities, presence of fever, cough, neurologic symptoms, headache, dysgeusia, dizziness, and smell impairment were similar between males and females $(p>0.05)$.

Among the 117 patients, 65 (55.5\%) were categorized into 
mild (non-complicated), 32 (27.4\%) into moderate (mild pneumonia), and 20 (17.1\%) into severe (severe pneumonia) disease group. Age, gender, presence of neurological complaints and smoking status didn't affect disease severity $(p>0.05)$. When laboratory tests were evaluated, higher ferritin and LDH levels and lower lymphocyte correlated with the worse disease severity ( $\mathrm{p}<0.001$ for all analyses) (Table 1).

The patients with any accompanying comorbidity were more likely to have a more severe disease group $(p=0.017)$. A significant correlation was found between hypertension and disease severity $(\mathrm{p}=0.046)$. However, it is not true for diabetes $(p=0.68)$. We also grouped our patients due to the number of comorbidities as having no comorbidity, a single comorbidity, and multiple comorbidities. There was not a direct correlation between the number of comorbidities and disease severity $(\mathrm{p}=0.17)$. However, the patients with multiple comorbidities had worse disease se- verity compared with the patients with no comorbidity ( $\mathrm{p}$ $=0.005)$. No significant difference was detected between the patients with a single comorbidity and ones with no comorbidity in terms of severity $(\mathrm{p}=0.08)$.

Table 2 shows the clinical features and laboratory findings of patients with and without neurological symptoms. Patients with neurological symptoms were younger, and more likely to have accompanying comorbidities ( $\mathrm{p}=$ 0.047 and $p=0.041$, respectively). No significant differences were found in terms of gender, any particular comorbidity, fever, cough, or any laboratory parameter (Neutrophil, Lymphocyte counts, CRP, D-Dimer, Ferritin, Aspartate Aminotransferase (AST), Alanine Aminotransferase (ALT), LDH) between the group of patients with neurological symptoms and one of without neurological symptoms ( $p>0.05$ for all analyses). We also investigated whether the presence of the most common classical symptoms of COVID-19 (fever and cough) were correlated with

\begin{tabular}{|c|c|c|c|c|c|}
\hline & \multicolumn{5}{|c|}{ Disease Severity Group, No. (\%) } \\
\hline Characteristics and laboratory findings & $\begin{array}{l}\text { Whole study group ( } \mathrm{n} \\
=117)\end{array}$ & $\begin{array}{c}\text { Mild } \\
(\mathrm{n}=65)\end{array}$ & $\begin{array}{l}\text { Moderate } \\
(\mathrm{n}=32)\end{array}$ & $\begin{array}{l}\text { Severe } \\
(\mathrm{n}=20)\end{array}$ & p value ${ }^{*}$ \\
\hline Age $($ mean $\pm \mathrm{SD})$ & $53.08 \pm 15.63$ & $50.7 \pm 16.9$ & $53.5 \pm 15.5$ & $58.4 \pm 9.3$ & 0.15 \\
\hline Any Comorbidities & $68(59.1)$ & $32(49.2)$ & $19(59.3)$ & $17(85.0)$ & 0.017 \\
\hline \multicolumn{6}{|l|}{ Number of comorbidities } \\
\hline None & $49(41.8)$ & $33(50.7)$ & $13(40.6)$ & $3(15.0)$ & 0.065 \\
\hline 1 Comorbidity & $43(36.8)$ & $22(33.8)$ & $12(37.5)$ & $9(45.0)$ & \\
\hline 2 Comorbidities & $16(13.7)$ & $7(10.7)$ & $3(9.3)$ & $6(30.0)$ & \\
\hline$\geq 3$ Comorbidities & $9(7.7)$ & $3(4.6)$ & $4(12.5)$ & $2(10.0)$ & \\
\hline Hypertension & $39(33.3)$ & $21(32.3)$ & $7(21.8)$ & $11(55.0)$ & 0.046 \\
\hline Diabetes & $23(19.6)$ & $11(16.9)$ & $7(21.8)$ & $5(25.0)$ & 0.68 \\
\hline Nervous system symptoms (any) & $79(67.5)$ & $44(67.6)$ & $22(68.7)$ & $13(65.0)$ & 0.96 \\
\hline Smoking & $25(21.3)$ & $19(29.2)$ & $3(9.3)$ & $3(15.0)$ & 0.062 \\
\hline \multicolumn{6}{|l|}{ Count, x109 L } \\
\hline Neutrophil & & $5.2 \pm 4.0$ & $4.1 \pm 2.1$ & $6.3 \pm 3.8$ & 0.08 \\
\hline Lymphocyte & & $2.1 \pm 8.3$ & $1.43 \pm 0.6$ & $1.3 \pm 0.7$ & $<0.001$ \\
\hline CRP mg/L & & $38.2 \pm 48.2$ & $49.3 \pm 58.8$ & $48.9 \pm 43.2$ & 0.51 \\
\hline D-Dimer ugFEU/L & & $970.6 \pm 1418.5$ & $1082.6 \pm 1574.5$ & $1331.2 \pm 1891.4$ & 0.65 \\
\hline Ferritin mg/L & & $203.2 \pm 236.4$ & $494.7 \pm 573.7$ & $426.8 \pm 352.2$ & $<0.001$ \\
\hline LDH U/L & & $243.2 \pm 90.2$ & $251.2 \pm 86.8$ & $344.2 \pm 139.0$ & $<0.001$ \\
\hline
\end{tabular}


Sakarya Med J 2021;11(3):616-624

TUNÇ et alk., Neurologic Symptoms and COVID-19

\begin{tabular}{|c|c|c|c|c|}
\hline & No. (\%) & & & \\
\hline & $\begin{array}{l}\text { Whole study group } \\
\qquad(\mathrm{n}=117)\end{array}$ & $\begin{array}{l}\text { With Neurological symptoms } \\
\qquad(\mathrm{n}=79)\end{array}$ & $\begin{array}{l}\text { Without Neurological } \\
\text { symptoms } \\
(\mathrm{n}=38)\end{array}$ & $p$ value ${ }^{*}$ \\
\hline Age $($ mean $\pm \mathrm{SD})$ & $53.08 \pm 15.63$ & $54.8 \pm 15.8$ & $48.7 \pm 14.6$ & 0.047 \\
\hline \multicolumn{5}{|l|}{ Sex } \\
\hline Female & $57(48.7)$ & $41(51.9)$ & $16(42.1)$ & 0.98 \\
\hline Male & $60(51.3)$ & $38(48.1)$ & $22(57.9)$ & \\
\hline Any Comorbidities & $68(59.1)$ & $51(64.5)$ & $17(44.7)$ & 0.041 \\
\hline \multicolumn{5}{|l|}{ Number of comorbidities } \\
\hline None & $49(41.8)$ & $28(35.4)$ & $21(55.2)$ & 0.11 \\
\hline 1 Comorbidity & $43(36.8)$ & $34(43.0)$ & $9(23.6)$ & \\
\hline 2 Comorbidities & $16(13.7)$ & $12(15.1)$ & $4(10.5)$ & \\
\hline$\geq 3$ Comorbidities & $9(7.7)$ & $5(6.3)$ & $4(10.5)$ & \\
\hline Hypertension & $39(33.3)$ & $28(35.4)$ & $11(28.9)$ & 0.48 \\
\hline Diabetes & $23(19.6)$ & $17(21.5)$ & $6(15.7)$ & 0.46 \\
\hline Chronic Respiratory Disease & $14(11.9)$ & $9(11.3)$ & $513.1)$ & 0.78 \\
\hline Cardiac Disease & $10(8.5)$ & $8(10.1)$ & $2(5.2)$ & 0.37 \\
\hline Chronic Renal Disease & $9(7.6)$ & $6(7.5)$ & $3(7.8)$ & 0.95 \\
\hline \multicolumn{5}{|l|}{ Count, x109 L } \\
\hline Neutrophil & & $5.5 \pm 4.1$ & $4.3 \pm 2.1$ & 0.085 \\
\hline Lymphocyte & & $1.8 \pm 8.5$ & $1.6 \pm 0.7$ & 0.12 \\
\hline CRP mg/L & & $44.7 \pm 50.3$ & $39.6 \pm 51.2$ & 0.61 \\
\hline D-Dimer ugFEU/L & & $1125.6 \pm 1693.1$ & $932.36 \pm 1174.7$ & 0.52 \\
\hline Ferritin mg/L & & $329.5 \pm 405.7$ & $303.8 \pm 380.9$ & 0.74 \\
\hline AST U/L & & $33.8 \pm 23.8$ & $28.8 \pm 23.6$ & 0.39 \\
\hline ALT U/L & & $35.1 \pm 31.0$ & $29.3 \pm 25.4$ & 0.31 \\
\hline LDH U/L & & $264.3 \pm 99.7$ & $259.2 \pm 104.5$ & 0.80 \\
\hline Fever & $43(36.8)$ & 29 & 14 & 0.88 \\
\hline Cough & $81(69.2)$ & 56 & 25 & 0.48 \\
\hline
\end{tabular}

the most common neurological complaints or not. Patients with cough were less likely to have headache $(\mathrm{p}=0.043)$. The presence of fever didn't show any correlation with the presence of headache $(\mathrm{p}=0.52)$. The presence of fever or cough didn't show any correlation with dizziness, smell or taste impairment ( $p>0.05$ for all analyses).

Twenty five $(21.3 \%)$ patients were smokers in our study population. Fever, cough, disease severity, presence of neurological complaints, and common neurological symp- toms (headache, dizziness, smell and taste impairment) were similar between the smoking and non-smoking groups ( $p>0.05$ for all analyses) (Table 3 ). 
Sakarya Med J 2021;11(3):616-624

TUNÇ et alk., Neurologic Symptoms and COVID-19

\begin{tabular}{|c|c|c|c|}
\hline & No. (\%) & & \\
\hline & Smokers $(\mathrm{n}=25)$ & Non-smokers $(\mathrm{n}=92)$ & $\mathrm{p}$ value $^{*}$ \\
\hline Age (mean $\pm \mathrm{SD}$ ) & $55.04 \pm 18.3$ & $52.25 \pm 14.9$ & 0.43 \\
\hline Fever & $10(40.0)$ & $32(34.7)$ & 0.62 \\
\hline Cough & $16(64.0)$ & $66(71.7)$ & 0.45 \\
\hline \multicolumn{4}{|l|}{ Disease severity } \\
\hline Mild & $19(76.0)$ & $46(50.0)$ & \\
\hline \multicolumn{4}{|l|}{0.06} \\
\hline Moderate & $3(12.0)$ & $29(31.5)$ & \\
\hline Severe & $3(12.0)$ & $17(18.4)$ & \\
\hline Nervous system symptoms (any) & $16(64.0)$ & $63(68.4)$ & 0.67 \\
\hline Headache $(n=29)$ & $5(20.0)$ & $24(26.1)$ & 0.53 \\
\hline Hyposmia/Anosmia $(\mathrm{n}=30)$ & $6(24.0)$ & $24(26.1)$ & 0.83 \\
\hline \multicolumn{4}{|l|}{ Dysgeusia } \\
\hline$(\mathrm{n}=36)$ & $7(28.0)$ & $29(31.5)$ & 0.73 \\
\hline \multicolumn{4}{|l|}{ Dizziness } \\
\hline$(\mathrm{n}=19)$ & $3(12.0)$ & $16(17.3)$ & 0.51 \\
\hline
\end{tabular}

\section{DISCUSSION}

Our study researched the frequencies of neurological symptoms in non-critical COVID-19 patients and their associations with the demographic features, severity of illness, other clinical symptoms, and laboratory parameters. We detected that more than half of the patients with non-critical COVID-19 suffer from neurological complaints, mainly taste/smell impairment, headache, and dizziness. Patients with neurological symptoms were more likely to be in a younger age and have accompanying comorbidities. Gender or smoking status didn't affect the presence of neurological symptoms as well as the disease severity. Higher ferritin and LDH levels and lower lymphocyte counts and presence of hypertension indicated worse disease severity in our study population. Laboratory analyses and typical symptoms of fever and cough were similar between the group with neurological symptoms and one without neurological symptoms. Some of the patients diagnosed with COVID-19 in our study group did not show typical symptoms of cough and fever which should warn us regarding the atypical presentations during the pandemic.
The previous researches revealed the CNS as an additional target of SARS-CoV in past outbreaks. ${ }^{14}$ This situation raises the possibility regarding the presentation of some patients with neurological manifestations in the ongoing outbreak of COVID-19. In a large cohort including 1099 patients with laboratory-confirmed cases from 552 hospitals in China through January 29, 2020, the frequency of headache was reported as $13.6 \%$ which was lower than $24.7 \%$ in our study group. 1 The frequency was reported not to differ significantly between severe and non-severe disease groups in similar with our findings. This report during the early period of pandemic did not include any data regarding the other neurological symptoms. The frequency of the all neurological symptoms in our study population is $67.5 \%$ which is relatively higher than one in the previously reported by Mao et al (36.4\%) and similar with the study of Helms et al (67\%).6,11 Fever and cough were the commonest classical symptoms in similar with our study group. In our study, the most common symptoms are taste impairment, smell impairment, headache, and dizziness in order of frequency. In the study of Mao and colleagues, the most common neurological symptoms 
were reported as dizziness, headache, taste impairment, and smell impairment. ${ }^{6}$ They reported complaints of dizziness in $16.8 \%$ of their patients similar with our results. However, the frequencies of headache (13.1\%), taste impairment (5.6\%) and smell impairment $(5.1 \%)$ on their patients were lower than the ones in our study population. On the contrary, $88.0 \%$ and $85.6 \%$ of patients were reported gustatory and olfactory dysfunctions in the study of Lechien and colleagues, which reported a relatively higher rates than our data. ${ }^{15}$ In similar, Beltrán-Corbellini and colleagues reported that $80.6 \%$ of the patients experiencing a smell disorder, and $90.3 \%$ a taste disorder.16 On the other hand, the meta-analysis of $\mathrm{Li}$ and colleagues detected the symptoms rates of headache or dizziness as $12.1 \%$ which was lower than our data. ${ }^{17}$ In another study, Lee and colleagues reported similar frequencies as acute anosmia or ageusia was observed in $15.3 \%$ of the patients in the early stage of COVID-19 and in $15.7 \%$ of the patients with asymptomatic-to-mild disease severity in a large population questioned via telephone interview. ${ }^{18}$ They reported that the prevalence was significantly more common among females and younger individuals. In a recent clinical study, Moein and colleagues performed The University of Pennsylvania Smell Identification Test (UPSIT), a well-validated 40 -odorant test, to 60 confirmed COVID-19 inpatients and 60 age- and sex-matched controls, and reported that $98 \%$ of the patients exhibited some kind of smell dysfunction. ${ }^{19}$ The wide range of those reported frequencies probably results from the differences in disease severity and/or methodological issues regarding the questioning the complaints of the patients.

Angiotensin converting enzyme 2 (ACE2), which is present in many organs, including nervous system was shown to be a functional receptor for SARS-CoV-2. ${ }^{20}$ It would be interesting to see if the SARS-CoV-2 could be detected from CSF or isolated from CNS at autopsy from endothelium (well known to express the ACE2 receptors) within the zones adjacent to the necrotic areas. The possible mechanisms of the various neurological syndromes include direct viral neuronal injury, inflammation (secondary hyperinflammation syndrome or para- and post-infectious inflammation), post-infectious immune-mediated disorders, or the neurological consequences of severe systemic disorders (hypoxia, sepsis, hypercoagulability, hyperpyrexia, and critical illness). ${ }^{21,22}$ Future studies are needed to clarify whether the neurological symptoms are the consequences of chemosensorial alterations resulted from systemic inflammatory response or the direct manifestations of viral invasion into the neurons or their supporting tissues.

Mao and colleagues also reported that the patients with more severe infection were more likely to have neurological symptoms in 214 hospitalized COVID-19 patients. ${ }^{6}$ Their patients with CNS symptoms had lower lymphocyte levels, but similar neutrophil, CRP, D-Dimer, LDH, AST, and ALT levels compared with those without CNS symptoms. In similar with our results, they also did not detect any significant differences between the groups with and without neurological symptoms in terms of neutrophil, lymphocyte counts, CRP, D-Dimer, LDH, AST, and ALT levels. Differently, in our study population, the disease severity didn't affect the emergence of neurological complaints, but the comorbidities were more likely to accompany them. In addition we questioned the median time from illness onset to neurological complaint and found that its average was approximately 2.5 days. The age, gender, presence and number of comorbidities, and disease severity didn't affect this time period.

Taken together with the above-mentioned researches, the results of our study affirm that the patients with COVID-19 show an increased tendency to present with neurological symptoms, and that should attract attention when managing the suspected patients without typical symptoms, particularly.

We did not include asymptomatic and critically ill patients in our study. Most of the patients had mild symptoms 
(55.5\%). The patients with severe infection were more likely to have coexisting comorbidities and hypertension. The presence of multiple comorbidities results in a tendency to have a more severe Covid-19 disease, and higher ferritin levels, higher LDH levels and lower lymphocyte counts indicate worse disease severity in our study group. Similarly, patients treated in the intensive care unit were more likely to have underlying comorbidities in the study of Wang et al. ${ }^{23}$ Age, number of comorbidities, diabetes, presence of neurological complaints and smoking status didn't affect disease severity in our study. Consistent with our data, age, diabetes, presence of neurological complaints, except the dizziness in the study of Wang and colleagues, didn't affect disease severity in the previous studies. ${ }^{23.24}$ Hypertension was more common among severe patients and there was no association between smoking and severity of COVID-19 in the study of Guan et al.1 Similarly, fever, cough, disease severity, and common neurological symptoms were similar between smoking and non-smoking group in our study. Showing the lack of correlation between cough and smoking may be valuable because it shows that cough is a sign of the disease.

We performed some additional analysis about fever and cough. Interestingly, patients with cough were less likely to have headache and the presence of fever or cough didn't show any correlation with dizziness, smell or taste impairment. This is an important point because it shows that neurological complaints are separate symptoms of the disease and that do not occur as a result of systemic changes caused by fever or cough. It is commonly believed that headache is caused by an increase in intracranial pressure with exertion. ${ }^{25}$ We can speculate that coughing may reduce headache by opening the bronchi and reducing hypoxia. Further studies are needed to explain the exact clinical and pathological mechanisms of SARS-CoV-2 infection.

The major limitation of our study is its cross-sectional de- sign conducted in only two centers, which limits conclusion about the direction of the associations and precludes any inferences about the causality. All of the patients were evaluated during the hospitalization period. Therefore, some patients might not be captured if they experienced neurological symptoms later. Moreover, most of the data regarding the neurological complaints were based on subjective declarations of the patients, and we couldn't perform quantitative tests for smell and taste.

In summary, our findings demonstrated that more than half of the patients with non-critical COVID-19 experience neurological complaints. Though defining the pathogenetic mechanisms of neuroinvasion will be revealed in time, the future studies are warranted to further explore the spectrum and intensities of the neurological manifestations and with the long-term clinical follow up results in these patients. Since the patients are highly contagious during the incubation and early periods of the disease, recognizing atypical presentations may represent an important hidden source of early diagnosis which might be helpful for disease control.

\section{Ethics}

Ethics Committee Approval: Ethical approval was obtained from the Ethics Committee of $\mathrm{Xx}$ University for NonInterventional Studies (Date: 20.05.2020 No:71522473/7050.01.04/235). The study protocol was performed in accordance with the Declaration of Helsinki. This study was also approved by the ministry of health which is mandatory in our country during the pandemic. Informed Consent: Written informed consent was obtained from the participants.

\section{Conflict of Interest}

No conflict of interest was declared by the authors.

\section{Financial Disclosure}

The authors declared that this study received no financial support. 
Sakarya Med J 2021;11(3):616-624

TUNÇ et alk., Neurologic Symptoms and COVID-19

\section{References}

1. Guan WJ, Ni ZY, Hu Y, Liang WH, Ou CQ, He JX, et al. Clinical Characteristics of Coronavirus Disease 2019 in China. N Engl J Med 2020;382(18):1708-1720.

2. Johns Hopkins University \& Medicine. COVID-19 map. Baltimore, MD: Johns Hopkins University; 2020. https://coronavirus.jhu.edu/map.html. Accessed 01 August 2021.

3. Jin Y, Yang H, Ji W, Wu W, Chen S, Zhang W, et al. Virology, Epidemiology, Pathogenesis, and Control of COVID-19. Viruses 2020;12(4):372.

4. Lovato A, de Filippis C, Marioni G. Upper airway symptoms in coronavirus disease 2019 (COVID-19). Am J Otolaryngol 2020;102474.

5. Esakandari H, Nabi-Afjadi M, Fakkari-Afjadi J, Farahmandian N, Miresmaeili SM, Bahreini E. A comprehensive review of COVID-19 characteristics. Biol Proced Online 2020;22:19.

6. Mao L, Jin $\mathrm{H}$, Wang $M, H u Y$, Chen $\mathrm{S}, \mathrm{He} \mathrm{Q}$, et al. Neurological Manifestations of Hospitalized Patients with COVID-19 in Wuhan, China: a retrospective case series study. JAMA Neurol 2020;77(6):683-690.

7. Paterson RW, Brown RL, Benjamin L, Nortley R, Wiethoff S, Bharucha T, et al. The emerging spectrum of COVID-19 neurology: clinical, radiological and laboratory findings. Brain 2020;143(10):3104-3120.

8. Vacchiano V, Riguzzi P, Volpi L, Tappatà M, Avoni P, Rizzo G, et al. Early neurological manifestations of hospitalized COVID-19 patients. Neurol Sci 2020;41:2029-2031.

9. Membrilla JA, de Lorenzo Í, Sastre M, Díaz de Terán J. Headache as a Cardinal Symptom of Coronavirus Disease 2019: A Cross-Sectional Study. Headache Epub 2020 Sep 28.

10. Delorme C, Paccoud O, Kas A, Hesters A, Bombois S, Shambrook P, et al. Covid-19-related encephalopathy: a case series with brain FDG-PET/CT findings published online ahead of print, 2020 Aug 15. Eur J Neurol 10.1111/ene.14478.

11. Helms J, Kremer S, Merdji H, Clere-Jehl R, Schenck M, Kummerlen C, et al. Neurologic Features in Severe SARS-CoV-2 Infection. N Engl J Med 2020;382(23):2268-2270.

12. Kandemirli SG, Dogan L, Sarikaya ZT, Kara S, Akinci C, Kaya D, et al. Brain MRI Findings in Patients in the Intensive Care Unit with COVID-19 Infection. Radiology 2020;297(1):E232-E235.

13. COVID-19 (SARS-CoV-2 Infection) Guide; Study of National Science Commission of Turkey. April 14, 2020. (COVID-19 (SARS-CoV-2 Enfeksiyonu) Rehberi; Bilim Kurulu Çalışmast) Turkish. Available at: https://covid19bilgi.saglik.gov.tr/depo/rehberler/COVID-19_ Rehberi.pdf. Accessed May 14, 2020.

14. Lau K, Yu W, Chu C, Lau S, Sheng B, Yuen K. Possible central nervous system infection by SARS coronavirus. Emerg Infect Dis 2004;102:342-344.
15. Lechien JR, Chiesa-Estomba CM, De Siati DR, Horoi M, Le Bon SD, Rodriguez A, et al. Olfactory and gustatory dysfunctions as a clinical presentation of mild-to-moderate forms of the coronavirus disease (COVID-19): a multicenter European study. Eur Arch Otorhinolaryngol 2020;277(8):2251-2261.

16. Beltrán-Corbellini Á, Chico-García JL, Martínez-Poles J, Rodríguez-Jorge F, Natera-Villalba E, Gómez-Corral J, et al. Acute-onset smell and taste disorders in the context of Covid-19. a pilot multicenter PCR-based case-control study. Eur J Neurol 2020;10.1111/ene.14273.

17. Li LQ, Huang T, Wang YQ, Wang ZP, Liang Y, Huang TB, et al. COVID-19 patients clinical characteristics, discharge rate, and fatality rate of meta-analysis $J$ Med Virol 2020;92(6):577-583.

18. Lee Y, Min P, Lee S, Kim SW. Prevalence and Duration of Acute Loss of Smell or Taste in COVID-19 Patients. J Korean Med Sci 2020;3518:e174.

19. Moein ST, Hashemian SMR, Mansourafshar B, Khorram-Tousi A, Tabarsi P, Doty RL. Smell dysfunction: a biomarker for COVID-19. Int Forum Allergy Rhinol 2020;10.1002/alr.22587.

20. Hamming I, Timens W, Bulthuis ML, Lely AT, Navis G, van Goor H. Tissue distribution of ACE2 protein, the functional receptor for SARS coronavirus: a first step in understanding SARS pathogenesis. J Pathol 2004;2032:631-637.

21. Zubair AS, McAlpine LS, Gardin T, Farhadian S, Kuruvilla DE, Spudich S. Neuropathogenesis and Neurologic Manifestations of the Coronaviruses in the Age of Coronavirus Disease 2019: A Review. JAMA Neurol 2020;77(8):1018-1027.

22. Mehta P, McAuley DF, Brown M, Sanchez E, Tattersall RS, Manson JJ. COVID-19: consi der cytokine storm syndromes and immunosuppression. The Lancet 2020;395:1033- 1034.

23. Wang D, Ни B, Нu C, Zhu F, Liu X, Zhang J, et al. Clinical Characteristics of 138 Hospitalized Patients With 2019 Novel Coronavirus-Infected Pneumonia in Wuhan, China JAMA 2020;323(11):1061-1069.

24. Huang C, Wang Y, Li X, Ren L, Zhao J, Hu Y, et al. Clinical features of patients infected with 2019 novel coronavirus in Wuhan, China published correction appears in Lancet. 2020 Jan 30. Lancet 2020;39510223:497-506.

25. Allena M, Rossi P, Tassorelli C. Focus on therapy of the Chapter IV headaches provoked by exertional factors: primary cough headache, primary exertional headache and primary headache associated with sexual activity. J Headache Pain 2010;14:525-530. 